\title{
4
}

\section{MAPPING THE PERSIAN GULF PETROLEUMSCAPE}

\section{The Production of Territory, Territoriality, and Sovereignty}

\author{
Stephen J. Ramos
}

On the evening of March 15, 1954, Sir Rupert Hay, who served as British Political Resident in Bahrain from 1946 through 1954, addressed the Royal Geographical Society in London on the topic of "the Persian Gulf States and their Boundary problems." Society President J. M. Wordie introduced Hay as one with "intimate knowledge of the Persian Gulf States and their problems," which would be presented "as delicately as may be-because it is delicate ground where sea and land are concerned and where oil is underneath." ${ }^{2}$ In the tradition of colonial knowledge production throughout the British Empire, Hay went on to describe in detail the natural resources and geographic conditions of what were then the ten Trucial States and Muscat. ${ }^{3}$ Hay concluded that oil had brought new wealth to Gulf "shaikhdoms," particularly after the collapse of the pearl trade, but that it had also brought new problems, the most important being the "fixation of boundaries by land and sea" (Figure 4.1.). ${ }^{4}$

The Trucial States were part of a larger British protectorate system: the British would back particular ruling families through "truces" or pacts within their "sphere of influence," with the understanding that British interests would be supported in the region. ${ }^{5}$ Throughout the nineteenth and early twentieth centuries, these interests were mainly focused on peaceful passage along the maritime trade routes that connected Britain with its colonies in India and East Asia. In 1908, oil discovery in Persia brought British attention ashore. Within the British colonial political geography, the founding of the Anglo-Persian Oil Company moved the region from a peripheral western outlier of the Anglo-Indian orbit to a strategic center for British oil exploration and extraction. Upon entering the global petroleumscape, the Trucial States' colonial spatial order shifted, and the British required a new territorial regime that could properly domesticate, discipline, and organize the new extraction economy. ${ }^{6}$ Gulf territorial production simultaneously combined British national and imperial objectives with the corporate objectives of interested oil companies, each overlaid on indigenous territorial codes. The British established a composite cartographic order of constituent pre-nation-state urban, territorial, and legal frameworks. These processes have their own palimpsestic qualities and draw attention to more complex issues of causality for spatial and territorial configurations in the global petroleumscape. 


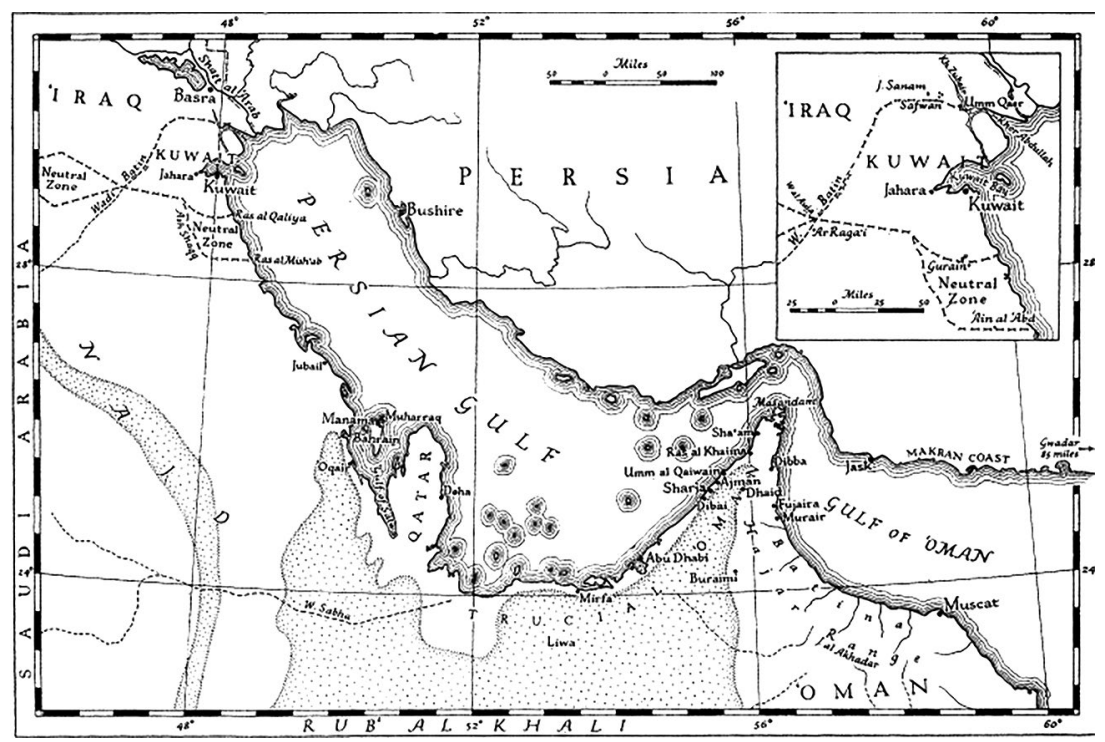

FIGURE 4.1 Map of the Persian Gulf in 1954, produced by Sir Rupert Hay. ${ }^{7}$ The Buraimi Oasis is located just southeast of Abu Dhabi and Dubai is labeled "Dibai."

By 1922, Kuwait, Bahrain, and the Trucial States had all signed agreements with the British, committing to granting oil exploration concessions only to companies appointed by the British government. Negotiations for these commitments included representatives from the British government, oil companies, and Gulf rulers. ${ }^{8}$ The trilateral, multifaceted interests of each of these parties foretell the complexity of the unique political and territorial configurations that such negotiations would produce. The situation was further complicated when corporate oil interests from allied countries such as the US and France entered the region soon after. ${ }^{9}$ The regional urban forms that emerge from this period are a product of the intertwined legacies of imperial rule and extractive capitalism. ${ }^{10}$ Large-scale trade infrastructure, such as ports and airports funded by new oil wealth, was also a generative element in Gulf urban and metropolitan formation. ${ }^{11}$ Subsequent territories, and the administrative territorialities that governed them, emerged as Trucial States moved through various subject relationships with international powers into their own respective, postcolonial, nation-state projects. Corporate interests catalyzed these regional transformations in territory and territoriality. As historian Rosemarie Said Zahlan states, "Oil firms forced rulers to define their frontiers, and thus to think of political power in [new] territorial terms, for the simple reason that they needed to know exactly what territories their concessions contained."12

The history of oil discovery, extraction, and distribution in the Gulf, and the wealth and sociocultural change that it brought to the region are well documented. ${ }^{13}$ Recent research estimates that Gulf monarchies, combined, produce over 17 million barrels of crude oil per day, nearly 20 percent of the global total, and they control approximately 37 percent of the world's proven crude reserves. ${ }^{14}$ Global production network (GPN) analysis literature maps the oil industry's strategic integration and geographic dispersion, and how the Gulf region serves as an important producer node within this geography. ${ }^{15}$ The global petroleumscape 
framework offers a comparative methodology to explore these broad historic spatial practices and representative modes of oil-its territoriality and materiality - to demonstrate the extent to which oil has constituted the essence of global modernity in the twentieth and early twenty-first centuries. ${ }^{16}$ As Hein writes, "Only in appreciating the power and extent of oil can we engage with the complex emerging challenges of sustainable design, policy making, heritage, and future built environments beyond oil.",17

The study of a world beyond oil is situated in a growing, interdisciplinary subfield of the post-oil imaginary, a futurism where transitions and inflection points lead the world to new energy distribution systems, presumably with their own spatialities and materialities. ${ }^{18}$ But if we follow Hein's metaphor, surely this new aspirational "post" phase will simply be another layer atop the accumulated, fragmented energy palimpsest. In her assessment of the Middle East, Janet Abu-Lughod describes how its cities "contain accretions of successive types of settlement," which in aggregate are all the more complex and challenging to comprehend. ${ }^{19}$ So, as far into the future as modes of extractive oil capitalism may continue, its legacy will continue beyond, shaping the world as another layer in the energy palimpsest. This is particularly true for the global petroleumscape's political influence on the negotiation of nation-state projects for both producer and consumer countries. The "power interdependencies" and the continued "centrality of the nation-state itself in the calculation oil accessibility and security" 20 are issues of energy power and historic geopolitics that will not simply vanish in the New Age. Path dependencies tether past to future, ${ }^{21}$ and in many parts of the world, the global petroleumscape has translated colonial dependencies into corporate ones. ${ }^{22}$ Over time, this fusion has led to the nation-state projects of the Gulf region. Political geographer Josh Barkan writes, "Put in ontological terms, it is through time that the potentiality of the world is actualized in new political forms" 23 - and the regional political and spatial transitions in the Gulf throughout the twentieth century are rich histories that help to illustrate this point. By fully appreciating the process of territorial production in the service of the global petroleumscape, we can better understand the degree to which Gulf state (quasi-colonial and postcolonial) and corporate interests were forged together at the petroleumscape's inception, and how territory and its organization (territoriality) were essential processes in the production of this new international petroleum order.

The global petroleumscape proposition presents a transversal historic material ethnography of oil and a reflexive political ethnography of its territoriality in the Gulf region. ${ }^{24}$ Just as Gulf region oil spatialities were produced by the geopolitical collaboration of late British colonialism and corporate oil, new spatial and political configurations arise from the multiparty collaborations that form the present nation-state and "global" conditions that continue to enable contemporary extractive capital flows. ${ }^{25}$

The chapter begins with a discussion of the concepts of territory, territoriality, and sovereignty as essential components in the negotiation and struggle for mapping. While the concept of mapping has grown recently to signify exploratory methodologies in spatial analysis and in the social sciences, ${ }^{26}$ here the process of mapping also considers its historic agency as both purveyor and arbiter of colonial and corporate power in a way that was essential to the production of the Gulf petroleumscape. British political philosopher Mark Neocleous describes the mapping of the modern state as an act of "cartographic violence in the construction of territory." 27 This description is useful within the broader British imperial project ${ }^{28}$ and also in the fixing of oil territories through state and corporate oil 
concession negotiations. By reviewing the construction and demarcation of Gulf territory and its affiliate territoriality administration of the regional transition during the ascendancy of the oil age, we can then begin to think about how these processes might continue to layer and metamorphosize "after oil." Put otherwise, by analyzing the complexity of the Gulf's historic layers of territory, territoriality, and sovereignty, we may begin to imagine its future through its past.

\section{Mapping Layered Territory, Territoriality, and Sovereignty}

In political geography, the concept of territoriality is used to explore the relationship between political systems and territory. ${ }^{29}$ Territory is both a political and geographical concept. Territory is not merely a natural phenomenon, but rather an organized space partitioned through political processes. ${ }^{30}$ US geographer Robert Sack defines territoriality as the "attempt by an individual or group to affect, influence, or control people, phenomena, and relationships, by delimiting and asserting control over a geographic area," namely, a territory. ${ }^{31}$ Alternatively, Swiss geographer Claude Raffestin defines territoriality as a system of relations translated physically and spatially, which constructs more than territory, and is constructed by factors that include and exceed territory ${ }^{32}$; territories, for Raffestin, are produced in the Lefebvrian sense. ${ }^{33}$ Although often framed within problematic cultural evolutionist claims, there is a distinct historic move from sociopolitical organizations of space, involving kinship, inheritance, or both, toward a more strictly defined political and spatial definition, which finds its maximum expression in the emergence of the nation-state. ${ }^{34}$ Taxonomies of premodern functional spatial configurations of territory include networks, nodes, hierarchies, surfaces, and movement. ${ }^{35}$ For these societies, nodal points might include wells, shrines, and ancestors' graves, which embed legibility and meaning in spatial configurations. ${ }^{36}$

With the emergence of the nation-state, an essential core attribute of territorial definition is the concept of property and exclusive, precise demarcation of borders with internal coherence and continuity. Rooted in Aristotelian logic and Greek geometry, Western property rights unite in a functional matrix, which in aggregate match the territorial demarcation claims of the state. ${ }^{37}$ Contracts gain authority over previous kinship understandings, and grosso modo, spatial definition and hierarchy, along with its administration, primed territories for industrial capitalism, for which the nation-state has proved to be the most effective guarantor. European colonial and imperial projects have extended this territorial definition of power relationships unevenly throughout much of the world, but as suggested by the palimpsest metaphor, these territorial configurations do not wholly erase the indigenous territorialities they sought to replace: "It is perhaps more accurate to say that it [European territoriality] was superimposed upon these existing forms, becoming tightly integrated with them in some areas while resting much less comfortably and stable in others." ${ }^{38}$ The transition from a politically organized unit to a nation-state is a process in constant flux, as is the perennial challenge to represent and document this process. ${ }^{39}$ Because territorial states are in a constant state of restructuring at the "intersection of local and global material conditions," bringing together domestic and foreign considerations and their different historic circumstances becomes the "overriding task." ${ }^{40}$ Nation-state territorialities preside over land (surface and subsurface), sea, air, ice, and rivers, which are all important for the extraction and distribution of oil. ${ }^{41}$ 
If territoriality is the presence of territorial definition and control, sovereignty is the authority to exert such control, often made explicit in law. ${ }^{42}$ But the relationship between sovereignty and law is complex. Critical literature on corporate sovereignty demonstrates the constitution of corporate and state sovereignty as conjoined and expressed over territories in specific spatial arrangements, such as imperial trading companies and free trade zones. These biopolitical processes are exercised over the border between the inside and outside of constituted political spheres ${ }^{43}$ : "In each case, it is not just the territorialization itself (the trade route, the free trade zone) but larger assemblages of power that enable these territorializations to come into being." ${ }^{, 44}$ For the global petroleumscape, often designed from a distance through colonial and corporate power, oil territory and imposed sovereignty was precisely the authority to fix and define territorial border demarcation, and immediately transgress those borders should concession interests and oil discovery require it for oil companies' externally-oriented resource extraction. This is the territorial contract of petroleumscape corporate sovereignty. Further, the new oil territoriality would essentially build on the nodal assemblage of the region's past, with oil wells, refineries, and circulatory infrastructure constituting new territorial "points and lines." Here the palimpsest's layers become difficult to discern in terms of which layer is at the fore at any given historic moment, or if they are simultaneously performing in concert.

In the Gulf region, British trade maritime routes began their territorial designation along the Trucial Coast (the southeastern Persian Gulf) in the early nineteenth century, and they proceeded inland with greater interest at the dawn of oil discovery and exploration. ${ }^{45}$ British intervention in regional boundary disputes, even for those states that were officially deemed protectorates, was never guaranteed. None of the three types of regional sovereignty laws - tribal, Islamic, and international — supported British territorial boundary demarcation authority. ${ }^{46}$ For the Trucial States, the right of the British to demarcate boundaries was "questionable, even if barely questioned." 47 In the 1920s, the British signed oil exploration agreements with oil companies and Gulf leaders to establish contractual legality as the definitional frame for territorial extraction rights, inscribing abstracted, linear geometric boundaries onto the shifting, sinuous region-land and sea-so as to avoid potential future conflict. ${ }^{48}$ Oil discovery creates a new territorial mandate. Again, Zahlan offers helpful insight: "Now that every inch of land had become potentially valuable, it was inevitable that conflicts over territorial definition would arise." ${ }^{, 49}$ In the oil exploration agreements, British imperial and corporate legality would serve as the arbiter of territorial definition.

The relationship between state formation and oil extraction in the UAE is further complicated by the fact that formation follows discovery in Dubai and Abu Dhabi (the latter has significantly more oil reserves), and the remaining Emirates are subordinated to these two with either significantly fewer or no oil reserves. ${ }^{50}$ In this context, to imagine a post-oil future is to completely upend the nation-state's foundational territorial construction, and to a large degree, its very essence. ${ }^{51}$ A review of the historic context of Britain's relationship to the region and the antecedent of a cartographic culture helps to inform the process of territorial construction in the Gulf's pre- and post-oil periods.

\section{British Cartographic Culture: Trade Territory}

Trade networks are inherently political territorial constructions in the service of imbricated public and private interests, and thus, "territorial enterprises." 52 British interests in the Gulf 
region begin in 1600, when Elizabeth I gave London merchants a monopoly charter to compete with the Portuguese in the spice trade, and the merchants soon acquired the name of the "East India Company." 53 The Dutch challenged the British for trade opportunities, but in 1765, after various conflicts among the European powers, the East India Company established control over the Mughal provinces. As imperial interests expanded, it was clear that the Company could earn great revenue as territorial administrator and land tax collector. The great achievement of the British Empire was to construct a single geographic state of India from its multitude of component polities and cultures through cartographic "colonial imaginings." ${ }^{24}$ British "cartographic culture" was not merely a sum of material map-making practices, but rather forms of territorial representation as the scientific legitimation of empire through the "rational construction of space." 55 British cartographic practices in India were constitutive of Enlightenment spatial ordering to legitimate imperial aspirations of wealth extraction. These same British practices also inform future territorial organization in the Gulf as the bountiful pearl industry of the late nineteenth century gave way to twentieth-century oil discovery. ${ }^{56}$ British cartographic practices also illuminate the interpenetration of the company's private entrepreneurial trade interests with British imperial strategy, and the defense and administration of each.

Piracy in the Gulf practiced by local Omani and Qawasim groups complicated European eastern trade routes throughout the eighteenth century, and created significant problems for the East India Company toward the end of the century. ${ }^{57}$ For the General Treaty of Peace in 1820, which included leaders from Bahrain and northern Oman (including areas of presentday UAE), all agreed to end piracy attacks. This began a series of truces in 1835, 1843, and 1853, whereby the British, through indirect rule, would "watch over and protect" the southern Gulf region. ${ }^{58}$ This policy of informal or indirect rule was based on the principle of "informal control if possible, formal control when necessary." 59 The "collaborators" in the lower Gulf were those tribal leaders in power at the time of trucial signing, and although British commitments to the region would eventually become more direct, before World War I, if trade routes went uninterrupted, Britain would only commit to maritime protection of the coastal pearling settlements of their sheikh cosignatories. ${ }^{60}$ If modern India is the creation of British cartography, the very origin and naming of the "Trucial Shaikhdoms" as a geographic entity is created from British imperial interests and their imperiled material trade concerns due to Gulf piracy. ${ }^{61}$

With the opening of the Suez Canal in 1869, French, Russian, German, and Ottoman expeditions began entering the Gulf region. In response, the British signed exclusive agreements with the Trucial States in March 1892, establishing that no territorial sovereignty could be ceded to any other international power without British consent. ${ }^{62}$ By 1916, similar treaties were signed by Bahrain, Kuwait, and Qatar, establishing a clear mare nostrum British administration of the Gulf region. At the beginning of the twentieth century, oil was discovered in Persia and Saudi Arabia, and shortly thereafter in Kuwait and Bahrain. ${ }^{63}$ Oil exploration was then carried out in all the British Gulf protectorates, which would require a more fixed territorial survey and demarcation rationale along with a new system of extraction infrastructures. But rather than replace an existing indigenous spatial order, oil territory and territoriality were superimposed on the desert and the sea. ${ }^{64}$ What follows is an overview of that pre-oil territory upon which the Gulf global petroleumscape was overlaid. 


\section{Pre-Oil Gulf Territory}

Within the tribal territorial dynamism that characterized the region before oil interests, coastal urban settlements were embedded in larger territorial relationships with the hinterlands and their societies. The region was generally organized around nomadic Bedu tribes in the interior who would charge a protection tax ("zakat") for safe passage through their territory ("dar"), smaller villages where tribes engaged in complementary fishing/agricultural activities, and the coastal towns where pearling and trade were centered. ${ }^{65}$ These coastal settlements mark the origin of subsequent urbanization processes of the region. ${ }^{66}$ It is this dynamic territorial configuration that better describes the "people-centered" nature of the territory, where violence and flux were ever-present. ${ }^{67}$ While authority emanated from coastal settlements, the measure of a coastal ruler's strength was the degree to which he could command Bedu support. ${ }^{68}$ The tribal territorial field involved multiple factions and constantly shifting allegiances, wherein dependence on tribal support meant that the Bedu were the "preponderant force" of the Trucial hinterland region, "able to hold Rulers, merchants, and common people to ransom," up to the early 1950s. ${ }^{69}$ Territorial sovereignty and demarcation were fluid and negotiated, and open movement across territory was an essential quality of the region's pre-oil territoriality. ${ }^{70}$

Restricted or exclusive territorial rights were reserved for areas that had been improved by labor and investment, such as irrigation land systems, extensive tree farming, wells, buildings, fish traps, and boats. ${ }^{71}$ "Usufructuary rights" could be negotiated with tribal leaders for their use, but this was markedly different from those unimproved areas of the territory, in that ownership was established by means other than common land use. ${ }^{72}$ These "improvements" were essentially responsive forms of infrastructure intended to harness the productive power of the territory according to varying contexts inland and on the coast. These investments required economic power, and this further entrenched the town as the center of territorial rule: "That no sheikh could rule his people without a command of economic power explains why all rulerships were town-based, at the heart of economic activity in the Gulf."73 Economic power allowed coastal rulers to buy Bedouin alliances and to invest in the infrastructure required for various forms of production and subsistence, where usufructuary rights served as an additional form of negotiated allegiance. Eventually, the power dynamic shifted to coastal settlements. British Trucial protégé rulers were able to claim territory in their hinterlands, thanks to British backing through oil concession stipends that helped them buy Bedu protection; implicit British Navy backing also helped ensure their protection. ${ }^{74}$ The British would enforce stricter corporate territory demarcation in the post-Ottoman negotiations and oil discovery at the early twentieth century. But infrastructure, such as wells and irrigation systems, coded the pre-oil indigenous territory in patterns of nodal functional composition, similar to those of the premodern societies mentioned above, and sovereignty, though located at coastal settlements, was continually negotiated with the Bedu periphery. ${ }^{75}$

The palimpsest metaphor for the global petroleumscape should suggest neither stasis nor harmony. The clashing of these territorial codes and understandings are constant and everpresent. The Buraimi Oasis, described below, helps to illustrate how the production and reproduction of global petroleumscape territory and territoriality was a violent, protracted international geopolitical struggle, occurring at multiple scales and time frames. 


\section{Contested British Boundaries: The Buraimi Oasis}

If the exclusive agreements of the region the British signed between 1892 and 1916 were useful for keeping other interested international powers away from the region, in the first part of the twentieth century, it was the British relationship with Ibn Saud-considered the founder of modern Saudi Arabia - that would prove most complicated. ${ }^{76}$ Ibn Saud led the country's territorial reunification from 1902 through 1932, and he ruled as Saudi monarch from 1932 through his death in 1953. Under his regency, oil was discovered in Saudi Arabia in 1938 by a US geologist working for the Standard Oil Company of New York, in cooperation with the Saudi government. ${ }^{77}$ Following World War II, a group of nine villages known collectively as the Buraimi Oasis, located at the southeastern corner of the Arabian Peninsula, was the site of regional conflict between Saudi expansionist interest and the territorial claims of Abu Dhabi, under British trucial protection. ${ }^{78}$ Oil prospecting was at the heart of the territorial conflict. ${ }^{79}$

In July 1913, the British had signed the first Anglo-Ottoman Convention to establish sovereignty for Kuwait, Qatar, and Bahrain, establishing the "Red Line" and the "Green Line" around Kuwait as stepped geometric demarcations of British protective spheres. ${ }^{80}$ The following year, a second set of lines — the blue and violet lines- had distinguished the British sphere of influence from the Ottoman in the south for Aden along rather arbitrary geometric meridian lines. In 1915, Ibn Saud signed an agreement with the British to contain his territorial interest in the Trucial States and officially recognize them in return for British recognition of Saudi rights to the Najd and Al-Hasa (the eastern region of what is now Saudi Arabia). ${ }^{81}$ In the 1930 s, oil exploration and concession rights brought back territorial disagreement between Ibn Saud and the British, and in 1935, after several negotiation attempts that included more nuanced understandings of tribal territoriality that were more sympathetic with Saud's position, the British again reverted to an abstract geometrical line termed the "Riyadh Line." 82 Saud rejected the line out of hand. The protracted negotiations were interrupted by World War II, and then resumed and intensified afterward. Saudi land claims moved eastward, reaching, according to the British, "grotesque proportions" in $1949 .{ }^{83}$ The British believed that their historic presence and maritime protection in the region had earned them influence and rights to its oil, a belief contested by Saud and the Persians (Figure 4.2).

A series of local, regional, and international meetings attempted to resolve the BritishSaudi territorial dispute, but they were unsuccessful. The conflict reached its apex in August 1952 when an armed Saudi group led by Turki bin Otaishan occupied the eastern Buraimi Oasis village of Hamasa, within the territory that the British considered to belong to the Abu Dhabi protectorate. ${ }^{84}$ The Buraimi villages marked the essential infrastructural feature for the grazing, nomadic economy, but there were also oil reserves identified in the area Saud's troops occupied, which would become the mineral and infrastructural land determinant in the next phase of the region. ${ }^{85}$ Saudi border disputes challenged British territorial interests for oil exploration and British political control of the region. The international scope of the Buraimi occupation was further complicated by the US oil interests' alignment with Saud in their joint oil enterprise, the Arabian-American Oil Company (ARAMCO). ${ }^{86}$ The British could not openly declare opposition to the US, so the proxy conflict among US and British oil interests played out in the territorial conflict in Buraimi, between Saudi Arabia and Abu Dhabi. 
In 1954, the Buraimi incident went to the International Arbitration Tribunal in Geneva, which also considered Oman's claims and Muscat's partial claims to the oasis lands. ${ }^{87} \mathrm{Ne}-$ gotiations broke down, and Britain reverted back to their geometrical land demarcation of a modified "Riyadh Line." 88 By the end of 1955, the British-backed security force known

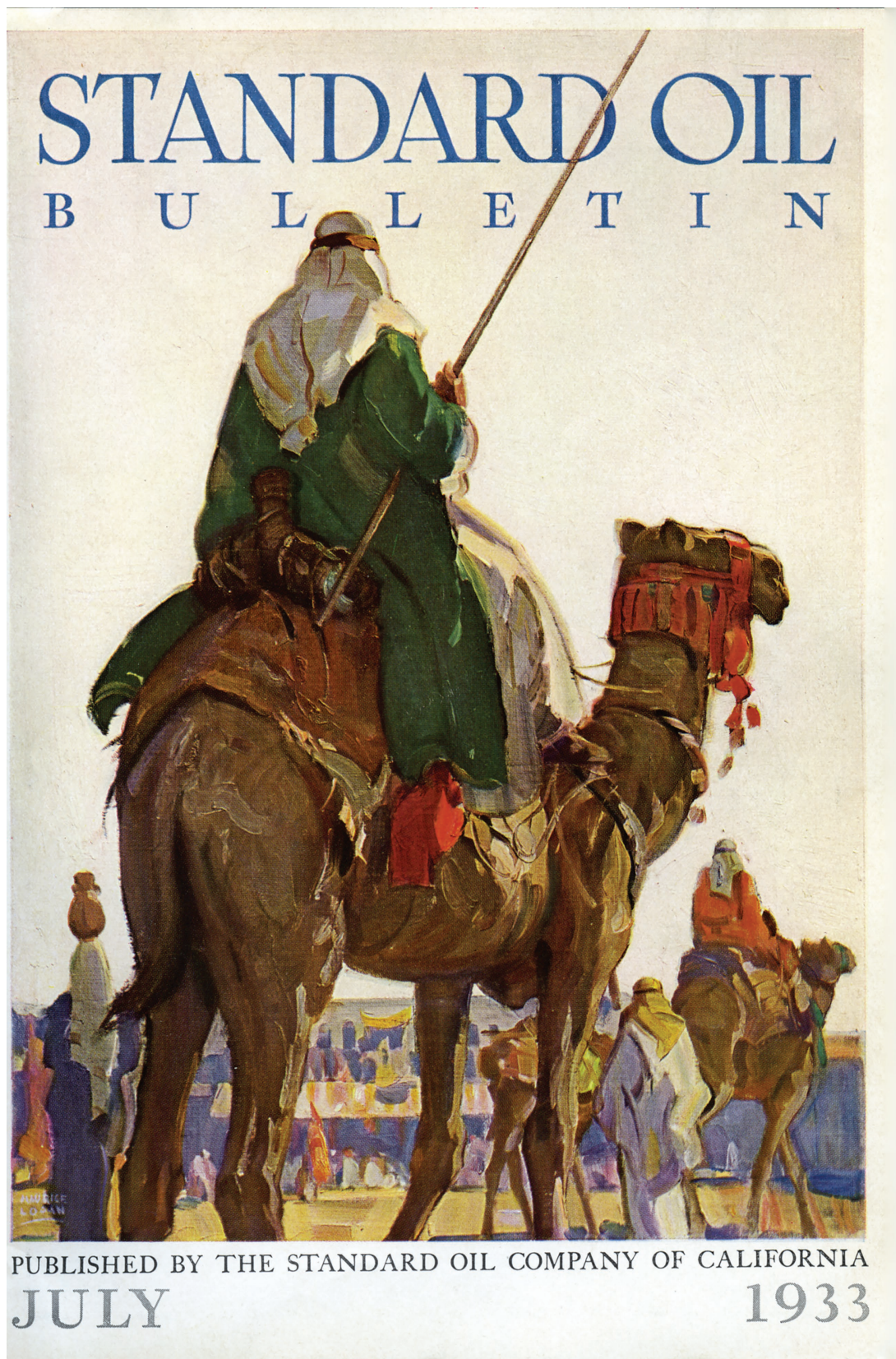

FIGURE 4.2 Cover image from the Standard Oil Bulletin published in July 1933. Standard Oil of California (Socal) established the Bahrain Petroleum Company (BAPCO) in 1929, and oil was discovered there in 1931. The company went on to sign an exploration agreement with Saudi Arabia, where oil was discovered in 1938 (Chevron Corporation). 
as the Trucial Levies (established in 1951 when local men were recruited to protect British nationals and their interests and to support their purported opposition to protectorate slave trade) entered the Buraimi village to evict the small Saudi army and unilaterally reestablish the "Riyadh Line." Saudi troops withdrew from Buraimi in 1955, but Saudi Arabia and Abu Dhabi would not resolve their territorial dispute until the 1974 regionally-brokered Treaty of Jeddah, ${ }^{89}$ after British withdrawal from the region in 1971.

The Buraimi incident drew the British into direct territorial conflict with Saudi Arabia, and by association, US oil interests. ${ }^{90}$ This was the first incident after British protectorate status was established for the Trucial States in 1949, and it explicitly conflated larger British strategic interests with the British Petroleum Development Trucial Coast (PDTC) oil exploration interests, much in the way that British interests and those of the East India Company had been conflated earlier. The modes of territorial negotiation moved from engagement with embedded Bedu knowledge of tribal tax and grazing land territorial outlines to the more abstract geometric lines drawn through British imperial fiat, one not ratified by official international diplomatic protocols. The historic allegiance between tribes and Ibn Saud made the British wary of that embedded knowledge, and they felt that any deference to tribal territorial understandings would undermine the authority they felt they were due, through over a century of serial, bilateral trucial agreements with select coastal leaders. ${ }^{91}$ Some historians claim that after India's 1947 independence, Britain began to develop a distaste for what they understood as the costs and responsibilities of empire. ${ }^{92}$ The Buraimi incident suggests that they were not entirely through with imperial pursuits.

Against the background of regional territorial boundary disputes, in 1955 the British sent land surveyor Julian Walker to the Trucial States to negotiate, organize, and delineate boundaries among sheikhs, so as to establish more precise, clear territorial boundaries and essentially insist on what it had enjoyed tacitly up to that point. Walker's boundary-marking expeditions through the desert harnessed British diplomatic networks and resources in the service of corporate extraction insurance. If rumblings of independence movements in Iran and Egypt were afoot in the region and ideologically spreading, then the British sought the security of fixed, internationally binding, and recognized borders in the service of the corporate petroleumscape.

\section{"Delicate Ground"}

When Sir Rupert Hay addressed the Royal Geographical Society in London, he described border disputes within the Trucial States and Muscat, including one that flared in 1948 when a Dubai raiding group killed fifty-two Manasir allies of Abu Dhabi in a border battle at Khor Ghanada. ${ }^{93}$ Dubai and Sharjah had fought over similar issues in 1940 and required leaders from Ras al-Khaima to help broker a truce. ${ }^{94}$ Hay also mentioned the Buraimi dispute in his address. Throughout 1954, internal territorial disputes were registered among Trucial States such that at the beginning of the following year, in January 1955, Julian Walker, then British Assistant Political Agent in Bahrain, set out on the "thankless job" of boundary settlement among Trucial rulers so that oil exploration could proceed. ${ }^{95}$

Before he set out, Walker claims to have found only scarce survey information produced by PDTC in the 1930s. In reviewing the British Agency communication from 1937 throughout the Trucial States, a British land agent found that rulers had only approximate knowledge of exact territorial limits. ${ }^{96}$ In the autobiographical literature of retired British diplomats that participated, these technical cartographical acts are described as having been 
reluctantly executed under the auspices of beneficence and regional development. ${ }^{97}$ What comes through clearly is the discomfort and concern of the protégé rulers in having to fix, within a limited time, land boundaries and their substrata resource claims, which were, in no uncertain terms, the symbolic and material sources of power.

For the first three months of 1955, Walker traveled on foot and via camel and Land Rover over Dubai's rugged terrain, interviewing tribesmen and trying to decode local and tribal geographic knowledge and translate it into map form. He used territorial signifiers, those features that demarcated ownership through improvement, to help identify and establish territorial boundaries and ownership. Irrigation channels and wells were the infrastructure that marked the territory and helped Walker identify ownership and political relationship based on its use as a clientelistic medium. ${ }^{98}$ Walker acted as both anthropologist and cartographer to settle boundaries as closely as possible to the satisfaction of those he interviewed, while knowing that the map itself would have to be completed with or without their approval. In his later accounts of his work, although recalling that he tried to represent as faithfully as possible the "local way of life" in his imposition of territorial "straight lines" in his surveying, Walker repeatedly underscores the fixity, dependability, and order in his work as giving transcendence and legacy to an otherwise (to his eye) chaotic territoriality. ${ }^{99}$

Upon completing his work, Walker wrote up the report and submitted it to the British Foreign Office for their approval, again, in keeping with the standard practices of colonial knowledge production. ${ }^{100}$ To Walker's surprise, the British government decided to put his report findings and boundary settlements on hold, believing his methodology and evidence in defining boundaries was "dangerously similar to that which the Saudis had put forward to bolster their claims against Abu Dhabi and the [Muscat] Sultanate."101 At the conclusion of the Buraimi settlement, once Saud's troops were removed, the British Foreign Office took up Walker's border proposal once more and asked that he return to negotiate the border proposal for final approval of Trucial rulers. There was a renewed urgency as PDTC wanted to begin drilling in Sharjah in 1957, and the British Foreign Office wanted boundary definitions approved and finalized by the rulers beforehand. ${ }^{102}$

\section{An Oil Urban Infrastructure}

While the Buraimi incident would not be settled until 1955, by late 1954 the Trucial Levies were able to build an airstrip at the Oasis to secure British access to the area. ${ }^{103}$ The airstrip provided the British Royal Air Force a base in case the conflict was to escalate. It would also establish a new kind of territorial claim through a new mode of infrastructural improvement as counterpoint to the traditional Buraimi wells. The airstrip served (along with its primary function) as one more territorial strategy deployed in hopes of defending British interests without military intervention. If engagement with tribal land knowledge systems was a "no-win" option for the British in securing their territorial interests vis-àvis Saud, then the linear form and fixity of road corridors, ports, and expanded buildings would serve as the urban infrastructure to accommodate oil extraction, development, and modernity. Timothy Mitchell refers to these infrastructures as "objects of development," and for the Gulf sheikhs they had the same appeal in their promise of ruling legitimacy. ${ }^{104}$ If they did not directly signify complete territorial sovereignty and control, then they at least pointed that way in domesticating what had, up until recently, been a competitive territory of ever-present violence. Coastal cities were the command centers for sheikh leadership with British backing, and regional urbanization infrastructure organized the territory to 
strengthen that central function for cities. ${ }^{105}$ Thus, the political and spatial organization of territory is the appropriate scale to understand Gulf urbanization, and the role of an urbanization infrastructure, built mainly by British engineering companies, codified that political and spatial co-organization (Figure 4.3). ${ }^{106}$

Urban infrastructure, principally oil-related, in the form of fixed circulatory infrastructure such as roads, ports, creek dredging, and airstrips (or creek airplane landings, as was the case for Dubai) spread across the Gulf petroleumscape, beginning in Kuwait once oil

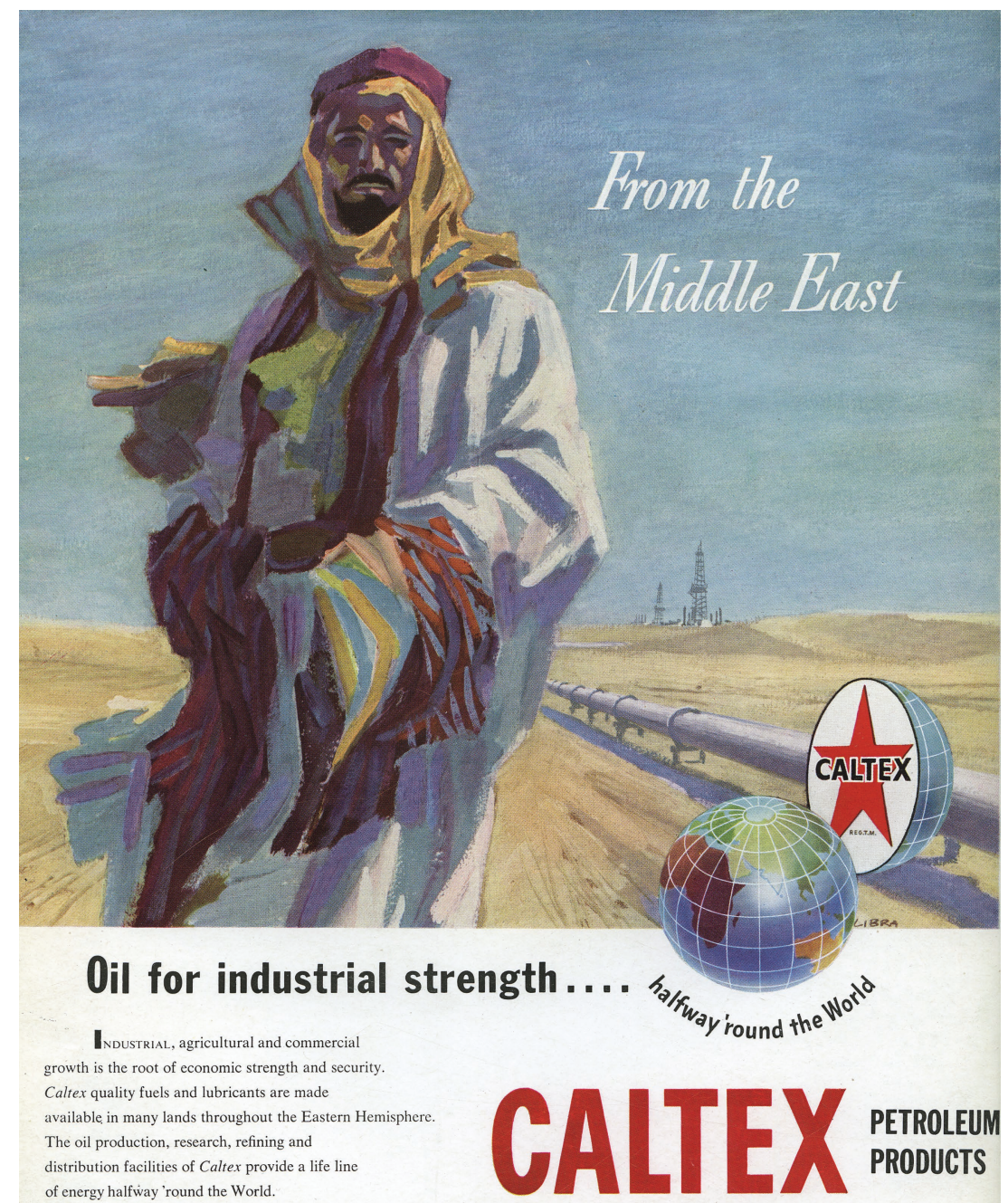

of energy halfway 'round the World.

Serving =UROPZ...AFRICA...ASIA...AUSTRALASIA

FIGURE 4.3 A 1952 California Texas Oil Company (Caltex) advertisement. Caltex was a joint venture between Socal and the Texas company in 1936. The declarative "From the Middle East...Serving Europe, Africa, Asia, Australasia" announces a new centrality for the region in the global petroleumscape (Chevron Corporation). 
was discovered there in $1938 .^{107}$ The British were able to harness their influence with rulers of the region through recommended British economic advisors. The advisors helped rulers modernize their states, suggesting that they spend oil exploration stipends and later oil revenue on the kinds of infrastructure projects that British engineering companies in the region were offering. ${ }^{108}$ British companies such as Sir William Halcrow's engineering firm moved much of their work to the Gulf region beginning in the mid-1950s, and they would remain in the region well after the British government officially left, having secured corporate interests to which they still felt historically entitled. ${ }^{109}$

The British withdrew from the region by 1971, but their legacy of oil infrastructure construction as a strategy for territorial claims continued into the nation-state period thereafter. A territory disagreement between Iraq and Kuwait was temporarily settled when the British ended their military protection of Kuwait in 1968, only to return in $1973 .{ }^{110}$ Iraq deployed military troops to the Kuwaiti northern territories and tried to force a treaty that would give them the right to build "refineries, depots and tanks for the storing of oil and water, bridges, harbors, airports, and railway lines" in the territory without having to pay. ${ }^{111}$ The incident was eventually settled through the Arab League, but it clearly demonstrates the use of oil infrastructure as a strategy to secure territorial claims, as the British did and as tribes did in their own "improvement" investment codes previously. The palimpsest of territory, territoriality, and sovereignty in the Gulf petroleumscape persists.

\section{Conclusion}

Claude Raffestin, discussing territoriality and the work of Henri Lefebvre, observed that "everyday life most often occurs in territorial morphologies that are not contemporaneous to the relations of which territoriality is woven." 112 For the Gulf petroleumscape, this both illuminates and reiterates the point that regional territorial production and reproduction, along with the respective management structures of territoriality, will likely continue beyond that future when oil dependency recedes. As a global petroleumscape case study, the Gulf illustrates the historical layering of spatial, material, and mapping practices. Within Gulf urban history, there are ongoing debates concerning how to properly gauge the causality of oil discovery in the region: Is oil the essential determinant of all socioeconomic, political, and cultural phenomena? ${ }^{113}$ Is there a definitive before and after oil-or a cumulative, catalytic carryover of previous relationships amassed more slowly over time? In many ways, these regional stories are most convincingly told through oil discovery as a central narrative, as an alternative, material history woven into traditional nation-state formation narratives. ${ }^{114}$ In the Gulf, the breadth and depth of regional oil centrality is proportional to the challenges it will face in transitioning to an after-oil period.

\section{Notes}

1 Rupert Hay, “The Persian Gulf States and Their Boundary Problems," Geographical Journal 120, no. 4 (1954): 433-43.

2 Ibid., 443.

3 Matthew H. Edney, Mapping the Empire: The Geographical Construction of British India 1765-1843 (Chicago, IL: University of Chicago Press, 1997); Nelida Fuccaro, "Knowledge at the Service of the British Empire: The Gazetteer of the Persian Gulf, Oman and Central Arabia," in Borders and the Changing Boundaries of Knowledge: Transactions 22, eds. Inga Brandell, Marie Carlson, and Önver A. Çetrez (Istanbul: Swedish Research Institute in Istanbul, 2015), 17-34; Timothy 
Mitchell, Rule of Experts: Egypt, Techno-Politics, and Modernity (Berkeley: University of California Press, 2002).

4 Hay, "Persian Gulf States," 443.

5 On December 2, 1971, seven of the Gulf States-Abu Dhabi, Ajman, Dubai, Fujairah, Ras al-Khaimah, Sharjah, and Umm al-Quwain - formed the United Arab Emirates (UAE) federation. Ras al-Khaimah officially joined two months later on February 11, 1972. See Shinhab M. A. Ghanem, Industrialization in the United Arab Emirates (Aldershot: Avebury, 1992).

6 Claude Raffestin, "Space, Territory, and Territoriality," Environment and Planning D: Society E Space 30 (2012): 121-41.

7 Map included in Hay, "Persian Gulf States."

8 Hassan H. Al-Alkim, "The United Arab Emirates and the Subregional Powers," in A Century in Thirty Years: Shaykh Zayed and the United Arab Emirates, ed. Joseph A. Kechichian (Washington, DC: Middle East Policy Council, 2000); Rosemarie Said Zahlan, "The Impact of the Early Oil Concessions in the Gulf States," in The Gulf in the Early Twentieth Century: Foreign Institutions and Local Responses, ed. R. I. Lawless (Durham: Centre for Middle Eastern \& Islamic Studies, 1986).

9 Morton, Michael Quentin, The Petroleum Gulf: The Discovery and Development of Offshore Oil in the United Arab Emirates (Abu Dhabi: UAE National Archive, 2016).

10 Alex Boodrookas and Arang Keshavarzian, "The Forever Frontier of Urbanism: Historicizing Persian Gulf Cities," International Journal of Urban and Regional Research 43, no 1 (2018): 14-29.

11 Stephen J. Ramos, Dubai Amplified: The Engineering of a Port Geography (Burlington: Ashgate, 2010); Stephen J. Ramos, "An Historical Examination of Territory and Infrastructure in the Trucial States," in Gateways to the World: Port Cities in the Persian Gulf, ed. Mehran Kamrava (Oxford: Oxford University Press, 2016).

12 Zahlan, "Early Oil Concessions"; William Hale, "Introduction," in The Gulf in the Early Twentieth Century: Foreign Institutions and Local Responses, ed. R. I. Lawless (Durham: Centre for Middle Eastern \& Islamic Studies, 1986), 3.

13 Toby Craig Jones, Desert Kingdom: How Oil and Water Forged Modern Saudi Arabia (Cambridge, MA: Harvard University Press, 2010); Timothy Mitchell, Carbon Democracy: Political Power in the Age of Oil (New York: Verso, 2011); Daniel Yergin, The Prize: The Epic Quest for Oil, Money, and Power (New York: Simon \& Schuster, 1991).

14 Christopher M. Davidson, After the Sheikhs: The Coming Collapse of the Gulf Monarchies (Oxford: Oxford University Press, 2013), 42.

15 Gavin Bridge, "Global Production Networks and the Extractive Sector: Governing Resource-Based Development," Journal of Economic Geography 8 (2008): 389-419.

16 Ibid.; Carola Hein, "Oil Spaces: The Global Petroleumscape in the Rotterdam/The Hague Area," Journal of Urban History 44, no. 5 (September 2018): 887-929, https://doi. org/10.1177/0096144217752460.

17 Hein, “Oil Spaces," 887.

18 Imre Szeman, "System Failure: Oil, Futurity, and the Anticipation of Disaster," in Energy Humanities: An Anthology, eds. Imre Szeman and Dominic Boyer (Baltimore, MD: Johns Hopkins University Press, 2017).

19 Janet Abu-Lughod, New York, Chicago, Los Angeles: America's Global Cities (Minneapolis: University of Minnesota Press, 1999), 3; Boodrookas and Keshavarzian, "Forever Frontier," 6.

20 Szeman, "System Failure," 59.

21 Hein, "Oil Spaces"; Andre Sorensen, "Taking Path Dependence Seriously: An Historic Institutionalist Research Agenda in Planning History," Planning Perspectives 30, no. 1 (2015): 17-38.

22 Hein, "Oil Spaces," 888.

23 Joshua Barkan, Corporate Sovereignty: Law and Government Under Capitalism (Minneapolis: University of Minnesota Press, 2013), 12-13.

24 Roger Owen, "Globalization at the Beginning of the Twentieth and Twenty-First Centuries," in Globalization and the Gulf, eds. John Fox, Nada Mourtada Sabbah, and Mohammed AlMutawa (Oxford: Oxford University Press, 2006), 79.

25 Barkan's use of the term "global" is appropriate: "Global' names an essential element in the way the potentiality of the past has been materialized in the present, along with the implicit spatiality structuring that process," Corporate Sovereignty, 14.

26 James Corner, “The Agency of Mapping: Speculation, Critique, and Invention,” in Mappings, ed. Denis Cosgrove (London: Reaktion Books, 1999); Denis Cosgrove, ed. Mappings (London: Reaktion Books, 1999). 
27 Mark Neocleous, "Off the Map: On Violence and Cartography," European Journal of Social Theory 6, no. 4 (2003): 409-25.

28 Edney, Mapping the Empire.

29 Robert D. Sack, Human Territoriality: Its Theory and History (Cambridge: Cambridge University Press, 1986).

30 Steward Elden, The Birth of Territory (Chicago: University of Chicago Press, 2013); Jean Gottmann, The Significance of Territory (Charlotte: University Press of Virginia, 1973); Henri Lefebvre, The Production of Space, trans. Donald Nicholson-Smith (Oxford: Blackwell, 1992 [1974]); Raffestin, "Space, Territory, and Territoriality."

31 Sack, Human Territoriality, 19.

32 Raffestin, "Space, Territory, and Territoriality," 126.

33 See also Hein, "Oil Spaces"; Lukasz Stanek, Henri Lefebvre on Space: Architecture, Urban Research, and the Production of Theory (Minneapolis: University of Minnesota Press, 2011).

34 Elden, Birth of Territory; Sack, Human Territoriality; E. W. Soja, "The Political Organization of Space," in Commission on College Geography Resource Paper 8 (Washington, DC: Association of American Geographers, 1971), 1-54.

35 Peter Haggett, Locational Analysis in Human Geography (New York: St. Martin Press, 1966), 6.

36 Soja, "Political Organization of Space," 13.

37 Denis Cosgrove, Geography and Vision: Seeing, Imagining and Representing the World (London: I. B. Tauris, 2008); Derek Gregory, Geographical Imaginations (Oxford: Blackwell, 1994).

38 Soja, "Political Organization of Space," 10.

39 Pirouz Mojtahed-Zadeh, Security and Territoriality in the Persian Gulf: A Maritime Political Geography (Richmond, Surrey: Curzon Press, 1999).

40 John Agnew, "The Territorial Trap: The Geographical Assumptions of International Relations Theory," in Mastering Space: Hegemony, Territory, and International Political Economy, eds. John Agnew and Stuart Corbridge (London: Routledge, 1995), 67; Robert W. Cox, "Social Forces, States, and World Orders: Beyond International Relations Theory," Millennium 10, no. 2 (1981): 126-55.

41 Nelida Fuccaro, "Between Imara, Empire and Oil: Saudis in the Frontier Society of the Persian Gulf," in Kingdom Without Borders: Saudi Arabia's Political, Religious, and Media Frontiers, ed. Madawi Al-Rasheed (Oxford: Oxford University Press, 2008); Soja, "Political Organization of Space," 33.

42 Giorgio Agamben, Homo Sacer: Sovereign Power and Bare Life (Stanford: Stanford University Press, 1998).

43 Barkan elaborates, "Sovereignty is the paradoxical structure of power that emerges out of a complex of concrete practices that attempt to govern life by establishing and transgressing the boundaries of law...corporate sovereignty emerges from and is exercised over the border between the inside and outside of constituted political spheres," Corporate Sovereignty, 7-8.

44 Ibid., 13.

45 Boodrookas and Keshavarzian, "Forever Frontier"; Nelida Fuccaro, Histories of City and State in the Persian Gulf: Manama Since 1800 (Cambridge: Cambridge University Press, 2009).

46 J. C. Wilkinson, "Nomadic Territory as a Factor in Defining Arabian Boundaries," in The Transformation of Nomadic Society in the Arab East, eds. Martha Mundy and Basim Musallam (Cambridge: Cambridge University Press, 2000).

47 G. Balfour Paul, The End of Empire in the Middle East: Britain's Relinquishment of Power in Her Last Three Arab Dependencies (Cambridge: Cambridge University Press, 1991), 113.

48 Dubai's oil discoveries were located on its offshore Fateh Fields, located in the Gulf, 60 miles off the Dubai coast. See Fuccaro, "Between Imara, Empire and Oil"; Morton, The Petroleum Gulf; Ramos, Dubai Amplified.

49 Zahlan, "Early Oil Concessions," 69.

50 Christopher M. Davidson, The United Arab Emirates: A Study in Survival (Boulder, CO: Lynne Rienner, 2005); Davidson, After the Sheikhs.

51 See discussion of state formation, urbanization, and citizenship in relation to oil in Nelida Fuccaro, "Pearl Towns and Early Oil Cities: Migration and Integration in the Arab Coast of the Persian Gulf," in Migration and the Making of Urban Modernity in the Ottoman Empire and Beyond, eds. Ulrike Freitag, Malte Furhmann, Nora Lafi, and Florian Riedler (London: Routledge, 2011), 99-116. 
52 Antoine Picon, “'What Has Happened to Territory?' Special Issue Territory: Architecture Beyond Environment," Architectural Design 80, no. 3 (2010): 94-99.

53 Edney, Mapping the Empire.

54 Benedict Anderson, Imagined Communities: Reflections on the Origin and Spread of Nationalism (New York: Verso, 1983); Edney, Mapping the Empire.

55 Edney, Mapping the Empire, 36.

56 Ibid.; Christopher A. Bayly, Empire and Information: Intelligence Gathering and Social Communication in India, 1780-1870 (Cambridge: Cambridge University Press, 2000); Felix Driver, Geography Militant: Cultures of Exploration and Empire (Oxford: Blackwell, 2001).

57 Richard F. Nyrop, Area Handbook for the Persian Gulf States (Washington, DC: American University, 1977).

58 Fauke Heard-Bey, From Trucial States to United Arab Emirates: A Society in Transition(London, New York: Longman, 1982).

59 James Onley, The Arabian Frontier of the British Raj: Merchants, Rulers, and the British in the Nineteenth Century Gulf (Oxford: Oxford University Press, 2007).

60 Hay, "Persian Gulf States."

61 Fatma Al-Sayegh, "Merchants' Role in a Changing Society: The Case of Dubai, 1900-90," Middle Eastern Studies 34, no. 1 (1998): 87-102.

62 Husain M. Al-Baharna, The Legal Status of the Arabian Gulf State: A Study of Their Treaty Relations and Their International Problems (Manchester: Manchester University Press, 1968); J. B. Kelly, "The Legal and Historical Basis of the British Position in the Persian Gulf," in St. Anthony's Papers: No. 4; Middle Eastern Affairs, Vol. 1 (London: Chatto \& Windus, 1958); James Onley, "The Politics of Protection: The Arabian Gulf Rulers and the Pax Britanica in the Nineteenth Century," Liwa: Journal of the National Center for Documentation and Research 1, no. 1 (2009): 25-46; Malcom C. Peck, The United Arab Emirates: A Venture in Unity (Boulder: Westview Press, 1986); David B. Roberts, "The Consequences of the Exclusive Treaties: A British View," in The Arab Gulf and the West, ed. Brian R. Prindham (London: Croom Helm, 1985).

63 Mitchell, Carbon Democracy; Yergin, The Prize.

64 Soja, "The Political Organization of Space."

65 Nelida Fuccaro, “The Making of Gulf Ports Before Oil," Liwa: Journal of the National Center for Documentation and Research 2, no. 3 (2010): 19-32; Julian Walker, "Social and Economic Developments in Trucial Oman in the First Half of the Twentieth Century," Liwa: Journal of the National Center for Documentation and Research 2, no. 3 (2010): 33-47.

66 Nelida Fuccaro, Histories of City and State in the Persian Gulf: Manama Since 1800 (Cambridge: Cambridge University Press, 2009).

67 Sulayman Khalaf, "The Evolution of the Gulf City Type, Oil, and Globalization," in Globalization and the Gulf, eds. John Fox, Nada Mourtada Sabbah, and Mohammed Al-Mutawa (Oxford: Oxford University Press, 2006); Onley, "Politics of Protection"; Henry Rosenfeld, "The Social Composition of the Military in the Process of State Formation in the Arabian Desert," Journal of the Royal Anthropological Institute of Great Britain and Ireland 95 (1965): 75-86; Richard N. Schofield and Gerald Blake, Arabian Boundary Disputes on the Arabian Peninsula (Cambridge: Archive Editions, 1988), 25; Rosemarie Said Zahlan, The Origins of the United Arab Emirates: A Political and Social History of the Trucial States (New York: St. Martin's Press, 1978).

68 Zahlan, United Arab Emirates, 6.

69 J. P. Tripp, "Political Agency, Trucial States. February 15, 1957 No. 6 Dispatch to Sir Bernard Burrows," in Arabian Boundary Disputes on the Arabian Peninsula, Vol. 22, ed. Richard N. Schofield (Cambridge: Archive Editions, 1991), 77.

70 J. C. Wilkinson, "Britain's Role in Boundary Drawing in Arabia: A Synopsis," in Territorial Foundations of the Gulf, ed. Richard N. Schofield (New York: St. Mark's Press, 1994).

71 Wilkinson, "Nomadic Territory," 45.

72 Wilkinson, "Britain's Role," 97.

73 Onley, "Politics of Protection," 29; Peter Lienhardt, "The Authority of Shaykhs in the Gulf: An Essay in Nineteenth-Century History," Arabian Studies 2 (1975): 61-75; James Onley and Sulayman Khalaf, "Shaikhly Authority in the Pre-Oil Gulf: An Historical-Anthropological Study," History and Anthropology 17, no. 3 (2006): 189-208.

74 Onley, "Politics of Protection."

75 Ramos, "Historical Examination." 
76 Fuccaro, "Between Imara, Empire and Oil."

77 Jones, Desert Kingdom.

78 J. B. Kelly, “The Buraimi Oasis Dispute," International Affairs, 32, no. 3 (1956): 318-26.

79 Michael Quentin Morton, "The Buraimi Affair: Oil Prospecting and Drawing the Frontiers of Saudi Arabia," Asian Affairs 46, no. 1 (2015), 1-17.

80 Ibrahim, Ibrahim, "Sovereign States and Borders in the Gulf Region: A Historical Perspective," in The Gulf Crisis: Background and Consequences, ed. Ibrahim Ibrahim (Washington, DC: Center for Contemporary Arab Studies, 1992); Krista E. Wiegand, "Resolution of Border Disputes in the Arabian Gulf," Journal of Territorial and Maritime Studies 1, no. 1 (2014): 33-48.

81 Michael Quentin Morton, Buraimi: The Struggle for Power, Influence and Oil in Arabia (London, New York: I. B. Tauris, 2013).

82 Richard N. Schofield, "Negotiating the Saudi-Yemeni International Boundary," Lecture delivered to the British Yemeni Society, March 31, 1999.

83 Balfour Paul, End of Empire.

84 Morton, Buraimi; Wiegand, "Resolution of Border Disputes."

85 Jones, Desert Kingdom.

86 Mitchell, Carbon Democracy.

87 Balfour Paul, End of Empire; Wilkinson, "Nomadic Territory"; J. B. Kelly, Arabia, the Gulf and the West, (London: George Weidenfeld \& Nicolson, 1980).

88 Wilkinson, "Nomadic Territory."

89 R. Seddiq, "Border Disputes on the Arabian Peninsula," in Policy Watch \# 525 (Washington, DC: Washington Institute, 2001); Wiegand, "Resolution of Border Disputes"; Wilkinson, "Nomadic Territory."

90 Julian Walker recounts that their British camp almost comes in conflict with an ARAMCO delegation near Buraimi in what he considered Abu Dhabi territory. Julian Walker, Tyro on the Trucial Coast (Durham: Memoir Club, 1999), 103.

91 Gwenn Okruhlik and Patrick J. Conge, "The Politics of Border Disputes on the Arabian Peninsula," International Journal (Toronto, Ont.) 54, no. 2 (1999): 230-48.

92 G. Balfour Paul, Bagpipes in Babylon: A Lifetime in the Arab World and Beyond (London: I.B. Tauris \& Co, 2006).

93 Walker, Tyro on the Trucial Coast.

94 Hay, "Persian Gulf States"; Ali Mohammed Khalifa, "The United Arab Emirates: Unity in Fragmentation-A Study in Ministate Integration in a Complex Setting, 1968-1976" (PhD diss., University of California, Santa Barbara, 1978).

95 Walker, Tyro on the Trucial Coast, 109; Tahira Yaqoob, "A Return to the Country He Drew," The National (November 25, 2008), https://www.thenational.ae/ uae/a-return-to-the-country-he-drew-1.484490

96 Zahlan, United Arab Emirates, 148; George Joffé, "Concepts of Sovereignty in the Gulf Region," in Territorial Foundations of the Gulf, ed. Richard N. Schofield (New York: St. Mark's Press, 1994).

97 Fuccaro, "Knowledge at the Service of the British Empire"; Joffé, "Concepts of Sovereignty.".

98 Julian Walker, "Practical Problems of Boundary Delimitation in Arabia: The Case of the United Arab Emirates," in Territorial Foundations of the Gulf, ed. Richard N. Schofield (New York: St. Mark's Press, 1994), 114.

99 Ibid., 116.

100 Edney, Mapping the Empire; Fuccaro, "Knowledge at the Service of the British Empire"; Mitchell, Rule of Experts.

101 Walker, Tyro on the Trucial Coast, 121.

102 Ibid.

103 Ibid., 98.

104 Stephen Graham and Simon Marvin, Splintering Urbanism: Networked Infrastructures, Technological Mobilities and the Urban Condition (London: Routledge, 2001); Jones, Desert Kingdom; Brian Larkin, Signal and Noise: Media, Infrastructure, and Urban Culture in Nigeria (London: Duke University Press, 2008); Mitchell, Rule of Experts, 201.

105 Michael Mann, "The Autonomous Power of the State: Its Origins, Mechanisms and Results," Archives Européennes de Sociologie 25 (1984): 185-213.

106 Ramos, "Historical Examination." 
107 See chapters by Fuccaro and Hindelang, this volume; Owen, "Cities of the Persian Gulf."

108 Balfour Paul, End of Empire; Antoine Benjamin Zahalan, The Arab Construction Industry (New York: St. Martin's Press, 1984).

109 Ramos, Dubai Amplified.

110 Ibrahim, "Sovereign States."

111 Kelly, Arabia, the Gulf and the West, 283.

112 Raffestin, "Space, Territory, and Territoriality," 129

113 Boodrookas and Keshavarzian, "Forever Frontier"; Fuccaro, "Knowledge at the Service of the British Empire"; Khalaf, "The Evolution of the Gulf City Type."

114 William Cronin, Nature's Metropolis Chicago and the Great West (New York: W.W. Norton \& Co., 1992). 